\title{
DETERMINANTS OF NEONATAL ASPHYXIA AT PILGRIMAGE HOSPITAL IN MEDAN, NORTH SUMATERA
}

\author{
Eka Susanti, Rahayu Lubis \\ Masters Program in Public Health, Universitas Sumatera Utara
}

\begin{abstract}
Background: According to WHO, 4 million neonatal deaths occurred each year due to birth asphyxia. Birth asphyxia is an insult to the fetus or newborn due to failure to breath or breathing poorly, leads to decrease oxygen perfusion to various organs. This study aimed to exaimne the determinants of birth asphyxia at Pilgrimage hospital in Medan, North Sumatera.

Subjects and Method: This was a case control study conducted at Pilgrimage Hospital, Medan, North Sumatera. A sample of 180 newborn infants was selected for this study. The dependent variable was birth asphyxia. The independent variables were maternal age, gestational age (prematurity), and infant birth weight. Data on asphyxia was obtained from the medical record. The other data were collected by questionnaire. The data were analyzed by a multiple logistic regression.

Results: The risk of birth asphyxia increased with maternal age $<20$ years or $\geq 35$ years $(\mathrm{OR}=6.25 ; 95 \% \mathrm{CI}=1.33$ to $29.03 ; \mathrm{p}=0.023)$, premature birth $(\mathrm{OR}=$ $7.90 ; 95 \% \mathrm{CI}=3.90$ to $16.02 ; \mathrm{p}=0.007)$, and low birth weight $(\mathrm{OR}=11.51 ; 95 \%$ $\mathrm{CI}=4.89$ to $19.82 ; \mathrm{p}=0.049$ ).
\end{abstract}

Conclusion:Birth asphyxia is associated with maternal age $<20$ years or $\geq 35$ years, premature birth, and low birth weight.

Keywords: birth asphyxia, maternal age, prematurity, low birth weight.

\section{Correspondence:}

Eka Susanti Lubis. Masters Program in Public Health, Universitas Sumatera Utara, North Sumatera. Email: ekasusantilubis@yahoo.co.id.

Mobile: 082165384690, o81533158603

The 4th International Conference on Public Health

Best Western Premier Hotel, Solo, Indonesia, August 29-30, 2018 | 192 https://doi.org/10.26911/theicph.2018.03.23 